\title{
Importância dos Anais
}

A grande importância dos anais está na divulgação do conhecimento que certamente beneficiará quem não estiver presente ou mesmo os presentes que quiSerem consultá-los posteriormente.

Outra relevância está no registro histórico. Toda sociedade médico-científica, como a SBACV, tem que ter muito bem registrada sua memória. O que foi demostrado e discutido neste evento científico não pode se perder, tem que ficar registrado.

Em um evento monotemático como este em que é tratado um unico tema, qual seja a flebologia e não outros assuntos, pode-se ser muito profundo e discutir amplamente, contando com a contribuição de notáveis conhecedores do assunto, nacionais e estrangeiros. Logicamente tudo deve ser cuidadosamente registrado. Assim temos que enfatizar, salientar a importância destes anais que registram o evento mais importante dessa area no Brasil. 